\title{
Fruits of the Bibles
}

\author{
Jules Janick \\ Department of Horticulture and Landscape Architecture, 625 Agriculture Mall Drive, Purdue University, \\ West Lafayette, IN 47907-2010
}

Additional index words. almond, date, fig, grape, olive, pomegranate

\begin{abstract}
The sacred writings of three religions (Judaism, Christianity, and Islam) are contained in the Hebrew Bible (referred to by Christians as the Old Testament), the Christian Bible (New Testament), and the Qur'an (Koran). These writings encompass events occurring over a period of more than two millennia and taken together represent a broad picture of mideastern peoples, describing their interactions with the sweep of events of that era. The writings include the sacred and profane, prose and poetry, history and myth, legend and fable, love songs and proverbs, parables and revelations. The basic agricultural roots of desert people are infused in the texts. Plants, plant products, and agricultural technology are referred to in hundreds of verses. References to fruits are abundant so that these bibles can be read almost as a pomological text in addition to the religious and sacred meanings that still inspire billions of people.
\end{abstract}

The plants of the bibles have long been of historic interest despite the many translation problems. The Hebrew bible was written in Hebrew and Aramaic, translated into Greek in the second century BCE, and then constantly translated into all the languages of the world, but the precise species originally referred to is unknown in a number of cases. In 1556, the plants of the bible were specifically dealt with in a book by Levinus Lemmes, and subsequently treated in a number of other works. In 1952, the indefatigable husband and wife team of Harold N. and Alma L. Moldenke compiled a treatise entitled Plants of the Bible (Fig. 1A) that includes key mentions of plants by chapter and verse, and assigned binomials, from 53 books of the Hebrew Bible and 27 of the Christian Bible (Authorized Version). This is a valuable source book for any study of biblical horticultural. The Moldenkes (Moldenke and Moldenke, 1952) refer to 230 species from Acacia nilotica to Zostera marina. They also provide chapter and verse for general references for which no particular plant can be identified, such as fruit (most common), herb, thicket, tree, grass, and forest. The Moldenkes cite "only the most important or interesting verses" (Moldenke and Moldenke, 1952), but nevertheless, the number of chapters cited gives some idea of the prominence of each fruit (Table 1); grape is clearly the most significant fruit of the bible.

One of the best sources of information on biblical fruits is the impressive work of Asaph Goor and Max Nurock (1968) entitled The Fruits of the Holy Land (Fig. 1B). This work not only covers the canonical texts of the Hebrew and Christian bibles, but also includes postbiblical Jewish commentaries including the Mishna (ca. $300 \mathrm{CE}$ ) and Talmud (ca. $600 \mathrm{CE}$ ). Fruits covered include grape, olive, fig, date, pomegranate, almond (the chief biblical fruits); citron (not specifically mentioned except in the noncanonical Book of Jubilees of the first century $\mathrm{CE}$ ); walnut (mentioned once in the Hebrew bible); carob (mentioned twice in the Christian bible); apple (mentioned three times in the Song of Songs, and a few times elsewhere, although the attribution is questionable because the Hebrew word tappuah may not refer to Malus); and pear, peach, apricot, plum, and banana (not mentioned in the canonical bibles).

A number of plants as well as horticultural and agricultural practices are mentioned in various verses of the Qur'an (Koran), the sacred book of Islam. References to fruits from this source were obtained from a translation of the Holy Qur'an by Shakir (1983).
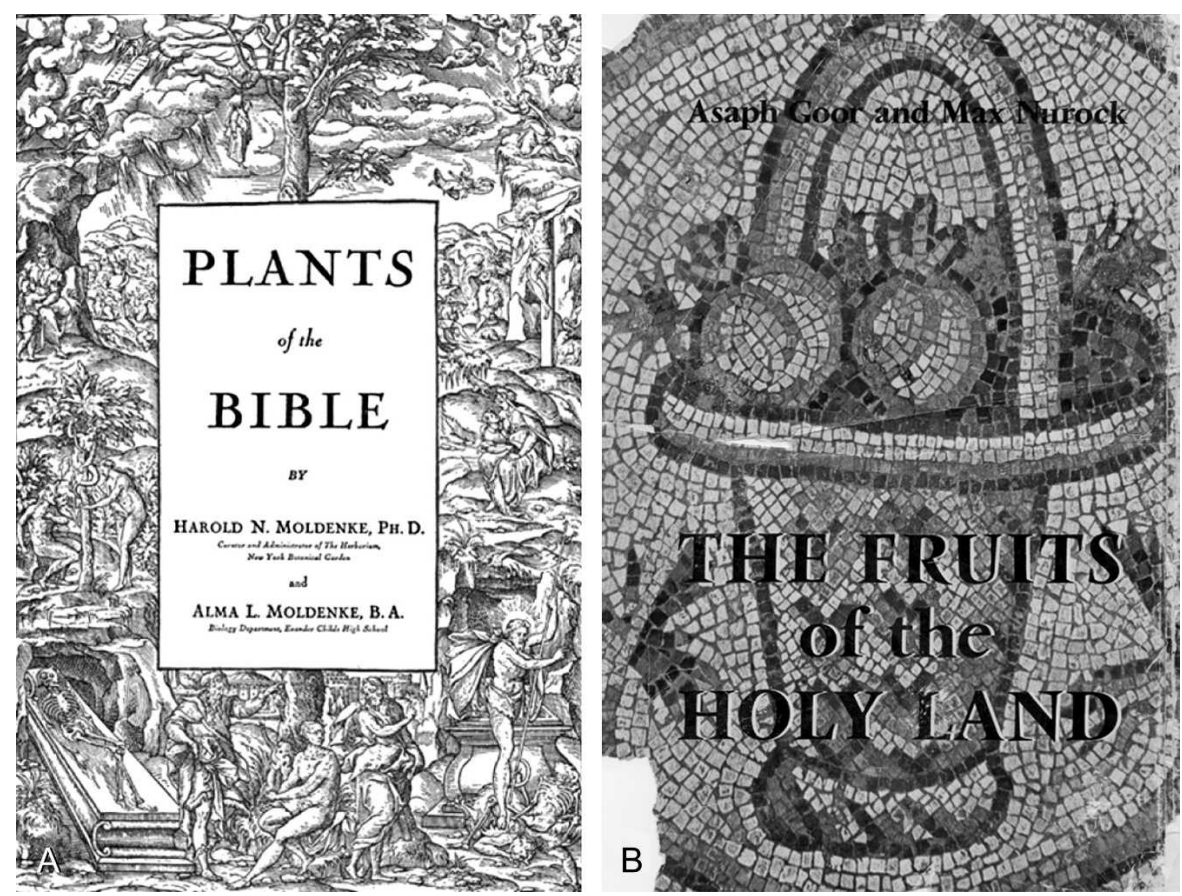

Fig. 1. (A, B) Frontispiece for Plants of the Bible by H.H. and A.L. Moldenke (A) and The Fruits of the Holy Land by A. Goor and M. Nurock (B).

Table 1. Number of chapters in Hebrew and Christian bibles that refer to specific fruits cited by Moldenke and Moldenke (1952) and number of mentions in the Qur'an (Shakir, 1983).

\begin{tabular}{lcccc}
\hline Crop & Hebrew Bible & Christian Bible & Qur'an & Total \\
\hline Grape & 72 & 6 & 12 & 90 \\
Olive & 48 & 12 & 6 & 66 \\
Date & 34 & 8 & 22 & 64 \\
Fig (two species) & 37 & 13 & 1 & 51 \\
Pomegranate & 23 & 0 & 3 & 26 \\
Almond & 10 & 0 & 0 & 10 \\
Apple (tappuah) & 5 & 0 & 0 & 5 \\
Walnut & 1 & 0 & 0 & 1 \\
\hline
\end{tabular}




\section{GRAPE (Vitis orientalis, $V$. vinifera)}

Both wild and cultivated grapes are referred to in the Hebrew bible. The wild grapes of the Old World $V$. sylvestris are indigenous to the South Caspian belt, Turkey, and the Balkans, and were widely distributed in the northern Mediterranean area including the Black and Caspian seas. Toward 5000 BCE and perhaps earlier, the domestic grape, $V$. vinifera, migrated from Anatolia to Syria and thence to the Holy Land. Signs of Bronze Age domestication are found in Mesopotamia, the Holy Land, Syria, Egypt, and the Aegean. By the second millennium $\mathrm{BCE}$, there is evidence of vessels for wine storage as well as raisins.

Grapes are easily propagated vegetatively, permitting extensive plantings of unique clones. The great genetic change in domestication was the switch from dioecism to hermaphroditism, increase in berry size and sugar content, and selection of various skin colors, and later, selection for seedlessness, a key factor for table grapes and raisins. The cultivation of grapes involves extensive vine training and pruning, and in no other fruit crops are these practices more important.

The Hebrew bible is rich in allusions to viticultural practices and wine making (Walsh, 2000). The replacement of tree supports with arbors or trellises is amply shown from Mesopotamian and Egyptian iconography (Fig. 2). Protection of grapes from birds and thieves is a common feature of the early cultivation of wine, and the construction of walls and towers is associated with vineyards in ancient Israel. Various techniques were developed for overwintering, including covering sprawling vines with soil, techniques that still exist in Afghanistan. Grapes were preserved by sun drying to produce raisins, or by transforming grape juice to wine. The culture of grapes and the technology of wine making are common themes in biblical writings, and become infused in Jewish and Christian religious practices and social encounters. Wine was associated with blessings and joy, although drunkenness was frowned upon. Grapes and raisins are highly prized in the Qur'an and, although wine is prohibited in Islam, "rivers of wine" are promised in Paradise.

\section{Biblical references}

Now will I sing to my wellbeloved a song of my beloved toughing his vineyard. My well beloved had a vineyard in a very fruitful hill. And he fenced it, and gathered out the stones thereof, and planted it with the choicest vine, and built a tower in the midst of it, and also made a winepress therein: and he looked that it should bring forth grapes, and it brought forth wild grapes. And now ... judge ... betwixt me and my vineyard. What could have been done more to my vineyard, that I have not done in it? Wherefore, when I looked that it should bring forth grapes, brought it forth wild grapes? Isaiah 5:1-7, 10

He took also of the seed of the land, and planted it in a fruitful field; he placed it by great waters, and set it as a willow tree. And it grew, and became a spreading vine of low stature, whose branches turned toward him, and the

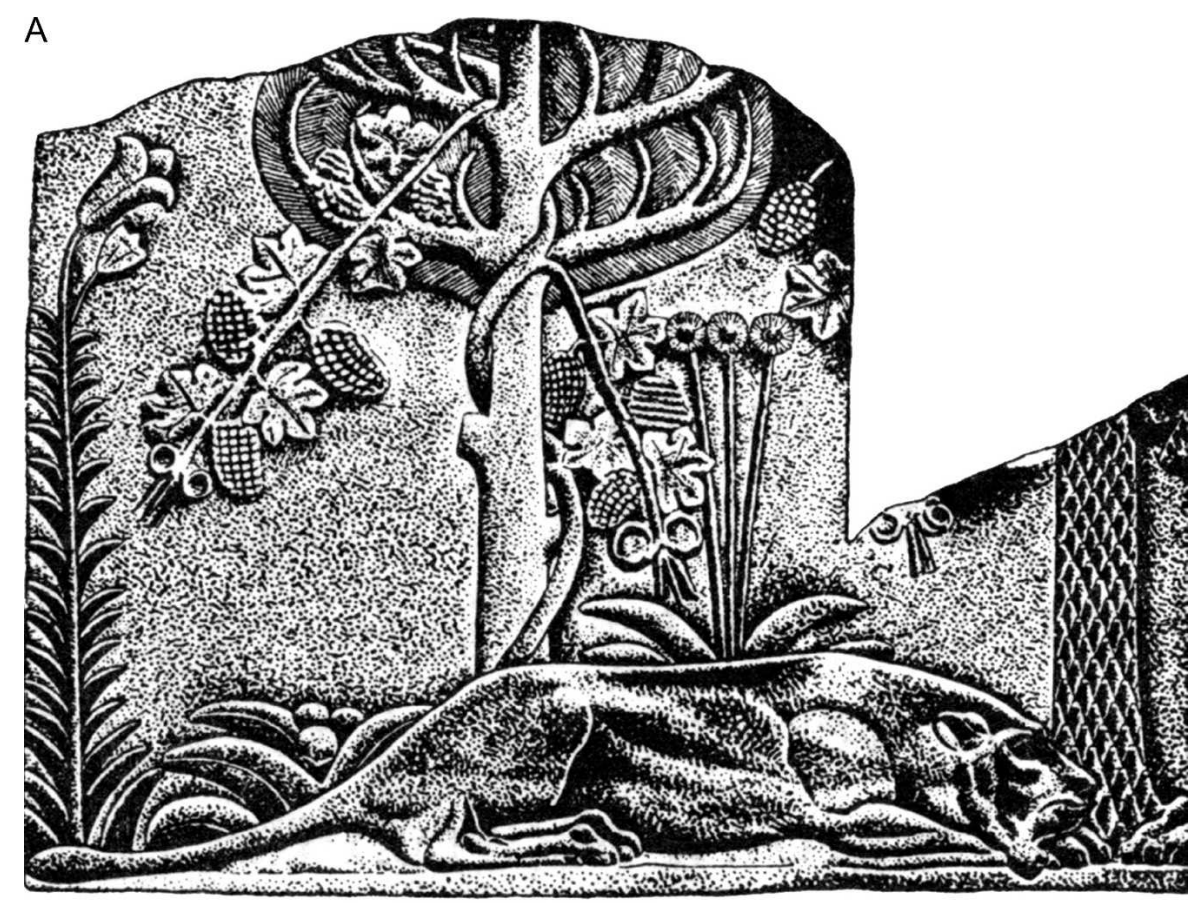

$B$

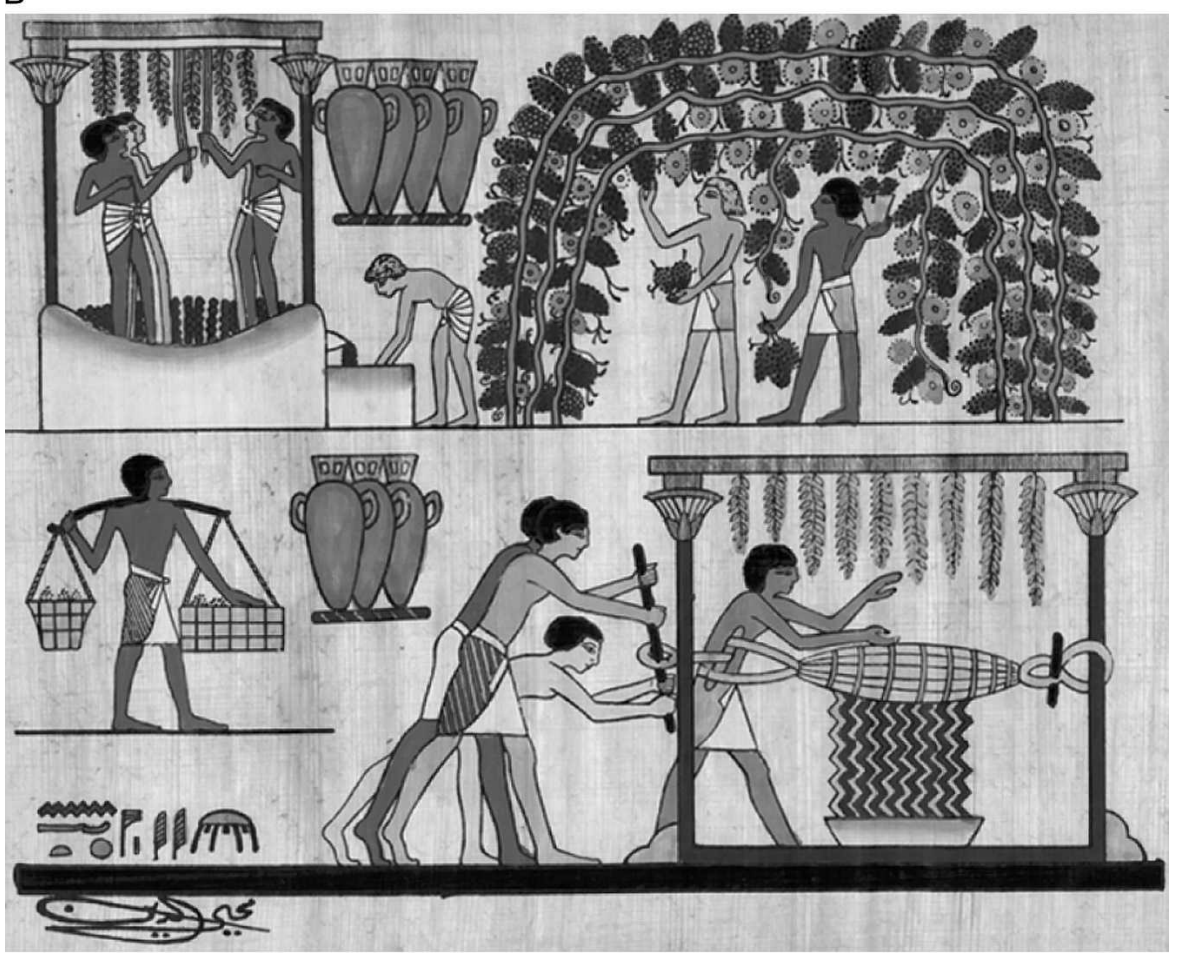

Fig. 2. (A) Vine climbing a cypress in an Assyrian garden. (B) Grapes collected from a round arbor from a tomb at Thebes, Egypt, ca. 1500 BCE and expressed by stomping and in a bag press. Source: Singer et al., 1954.

roots thereof were under him: so it became a vine, and brought forth branches, and shot forth sprigs. Ezekial 17:5-7

I am the true vine, and my Father is the husbandman. Every branch in me that beareth not fruit he taketh away: and every branch that beareth fruit, he purgeth it, that it may bring forth more fruit .... As the branch cannot bear fruit in itself, except it abide in the vine; no more can ye, except ye abide in me. I am the vine, ye are the branches: He that abideth in me and I in him, the same bringeth forth much fruit for without me ye can do nothing. If a man abide not in me, he is cast forth as a branch. and is withered; and men gather them and cast them into the fire, and they are burned. John 15:1-6

And He it is Who produces gardens (of vine), trellised and untrellised, and palms and seed-produce of which the fruits are of various sorts, and olives and pomegranates, like and unlike; eat of its fruit when it bears fruit, and 
pay the due of it on the day of its reaping, and do not act extravagantly; surely He does not love the extravagant. Qur'an, The Cattle:6.141

\section{OLIVE (Olea europa)}

The olive is a slow-growing, long-lived evergreen tree uniquely adapted to and a defining feature of the Mediterranean climate (Fig. 3). Archeological evidence of the olive dates to $\approx 10,000 \mathrm{BCE}$, whereas the cultivated olive originated $\approx 4000$ BCE in Asia Minor. The olive was not used by the Babylonians and Assyrians, whose sources of oil were sesame and walnut, but olive was long known in Syria and the Holy Land and was introduced to Egypt between 3000 and 1600 BCE. By the time of Ramses II (1197-1165 BCE) olive oil was used for illumination and as a skin emollient for cracks and sunburn.

The first use of olive oil was probably medicinal, but it became the first great industrial crop because of its use in illumination; the burning oil of olive gives a very luminous flame. Oil lamps of the ancient world are among the most common artifacts
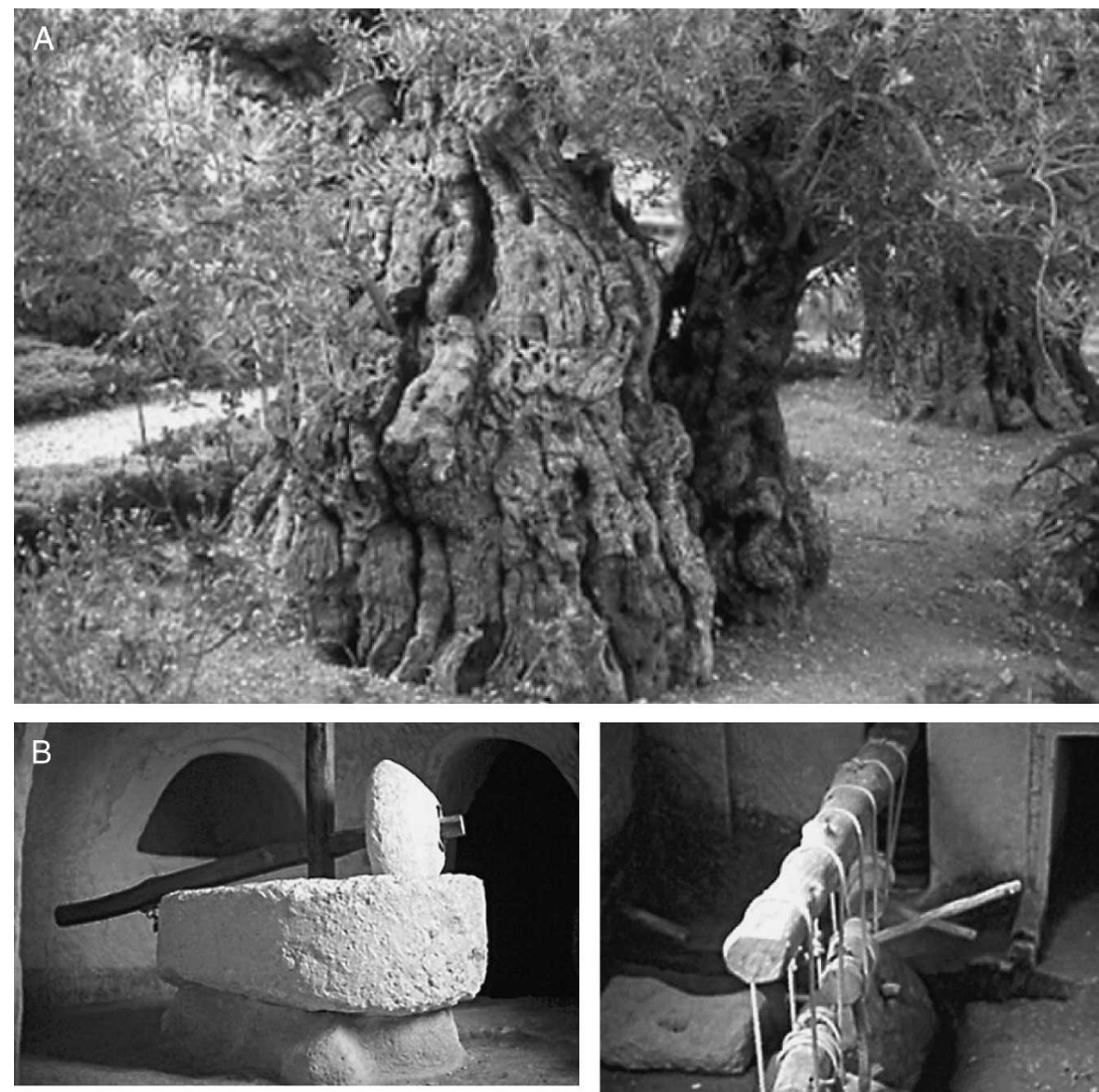

C
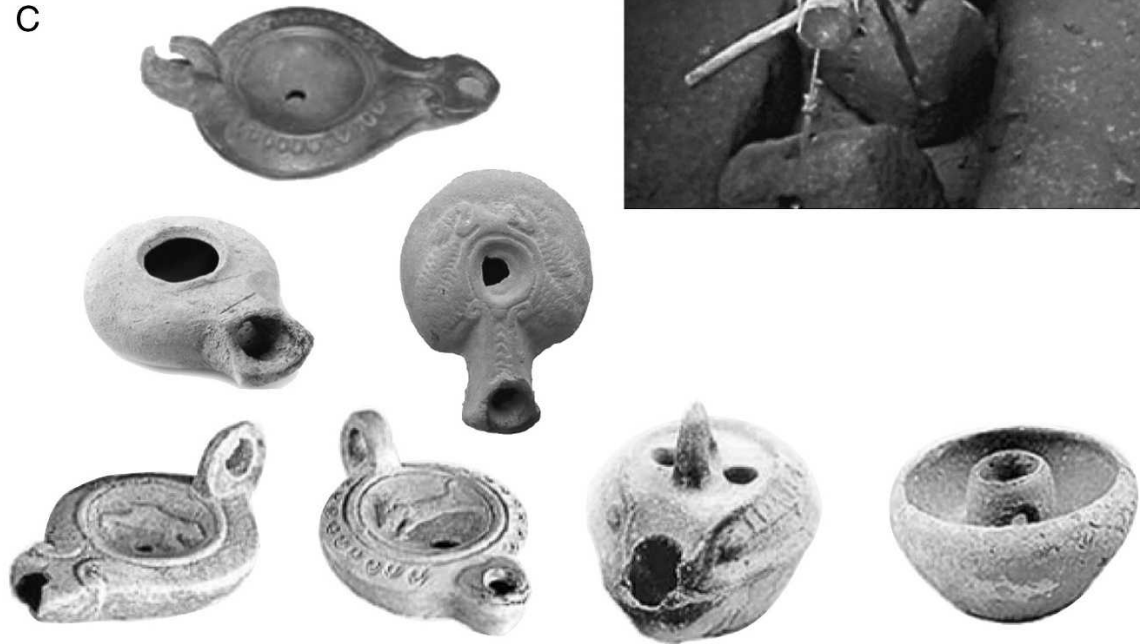

Fig. 3. (A-C) The olive. A tree in the Garden of Gethsemane (A) and ancient olive presses in Israel (B; photographs by J. Janick), and a collection of oil lamps from antiquity (C). of archeological digs in that area. The oil was also used in cooking and as a dressing, and is still the most common culinary oil in the Mediterranean area. Its use is now increasing for taste and health reasons because it is high in unsaturated fatty acids. The use of olives for food is an example of human ingenuity. Somehow humans learned that the small, bitter fruits, almost inedible and somewhat poisonous as a result of the phenolic glucoside eleuropein, could be made edible by soaking and fermentation. Selection in olive led to high oil content or large fruit for table use.

Olive, along with grape, is the most mentioned fruit in the Hebrew bibles and its importance permeated the western world. The olive tree became a symbol of beauty, freshness, fertility, wealth, fame, and peace. Its importance is reflected in its widespread use of oil for religious purposes such as consecration ceremonies (anointing) in Judaism and Christianity; the word messiah (Christ) literally means "the anointed one." Although grafting is not referred to in the Hebrew bible, grafting of olive is mentioned in the Christian bible (see Romans 11, later).

\section{Biblical references}

And thou shalt command the children of Israel that they bring thee pure oil olive beaten for the light, to cause the lamp to burn always. Exodus 27:20

The trees went forth on a time to anoint a king over them; and they said unto the olive tree, Reign thou over us. But the olive tree said unto them, Should I leave my fatness, wherewith by me they honour god and man ... Judges 9:8-9

And if some of the branches be broken off, and thou, being a wild olive tree, wert graffed in among them, and with them partakest of the root and fatness of the olive tree .... For if thou were cut out of the olive tree which is wild by nature, and were graffed contrary to nature in a good olive tree: how much more shall these, which be the natural branches, be graffed into their own olive tree? Romans 11:17, 24

And a tree that grows out of Mount Sinai which produces oil and a condiment for those who eat. Qur'an, The Believers:23.020

\section{DATE (Phoenix dactilifera)}

The date palm is a dioecious, long-lived, palm, indigenous from northern Africa through the Arabian peninsula to northern India, esteemed for its sweet fruit and its valuable wood and leaves (Fig. 4). It may have been the first cultivated fruit and was well established in the Middle East during the Bronze Age. The plant lacks a deep root system so that irrigation is essential. Because the date is dioecious, production of fruit by pistillate clones requires a source of pollen, and artificial pollination was well illustrated in Assyrian bas reliefs where the practice became codified in the laws of Hammurabi ca. $1750 \mathrm{BCE}$ and the practice became a religious practice.

\section{Biblical references}

And the plain of the valley of Jericho, the city of palm trees ... . Deuteronomy 2:8 
And he shall be like a tree planted by the rivers of water, that bringeth forth his fruit in his season; his leaf also shall not wither... Psalms 1:3

The righteous shall flourish like the palm tree ... . Those that be planted in the house of the Lord shall flourish .... They shall bring forth fruit in old age; they shall be fat and flourishing. Psalms 92:7-8

And of the fruits of the palms and the grapes-you obtain from them intoxication and goodly provision; most surely there is a sign in this for a people who ponder. Qur'an, The Bee:16.06

\section{FIG (Ficus carica, F. sycomorus)}

Two species of fig are mentioned in the bible: common fig (F. carica) and sycomore fig ( $F$. sycomorus). The common fig is a gynodioecious species consisting of monoecious inedible wild types (caprifig) and pistillate domesticates. Borne on small trees, figs are one of the classic Mediterranean fruits. Signs of fig cultivation are found at various Neolithic and late Neolithic sites. Domestication was generally contemporary with olive and grape in the eastern Mediterranean basin. Pollination is affected by a tiny wasp (Blastophaga psenes) that overwinters in the caprifig. The wasp, after emergence, enters the common fig, which contains only long-styled pistils, not adapted to oviposition, causing the wasp to perish, but not before pollination has occurred. The Tree of Good and Evil in the Genesis story of Adam and Eve was often depicted as a fig tree (Fig. 5).

The sycomore fig originated in the savannas of eastern Central Africa and was introduced into Egypt in predynastic times. It became an important cultivated plant for its decay-resistant wood and its fruit, which although not exceptional, was widely consumed. Because the pollinating wasp seems not to have been introduced, the fruits did not develop normally and ripening was achieved by scraping with a metal tool, an example of an innovative horticultural practice that relied on ethylene release from the wound response (Galil, 1968).

\section{Biblical references}

And the eyes of them both were opened, and they knew that they were naked; and they sewed fig leaves together, and made themselves aprons. Genesis 3:7 (Fig. 4)

And the trees said unto the fig-tree, come thou and reign over us. But the fig tree said unto them, should I forsake my sweetness, and my good fruit, and go to be promoted over the trees? Judges 9:10-11

I was not a prophet or a prophet's son but I was an herdsman, and a piercer [mistranslated as "gatherer" in the King James Bible] of sycomore fruit. Amos 7:14

And seeing a fig tree afar off having leaves, he came, if haply he find anything thereon: And when he came to it, he found nothing but leaves; for the time of figs was not yet ... and in the morning as they passed by, they saw the fig tree dried up from the roots. Mark 11:13, 20

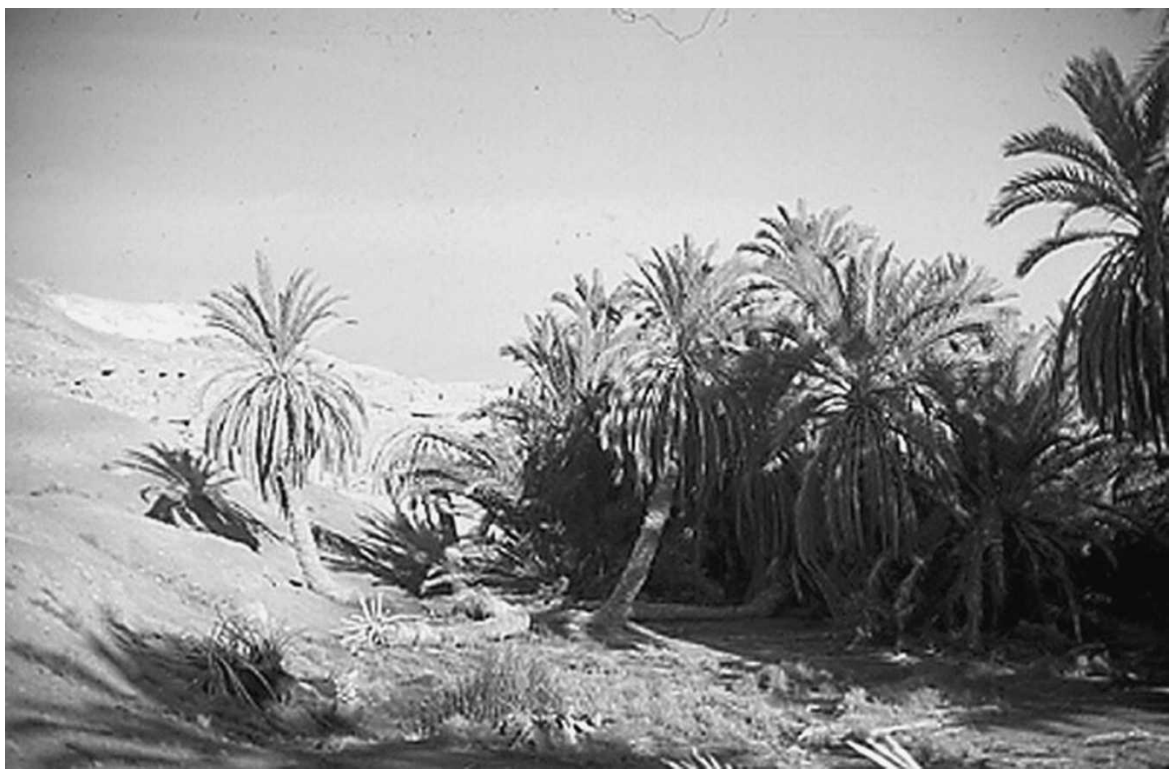

Fig. 4. Dates in an oasis in the Sinai peninsula. Photograph by J. Janick.

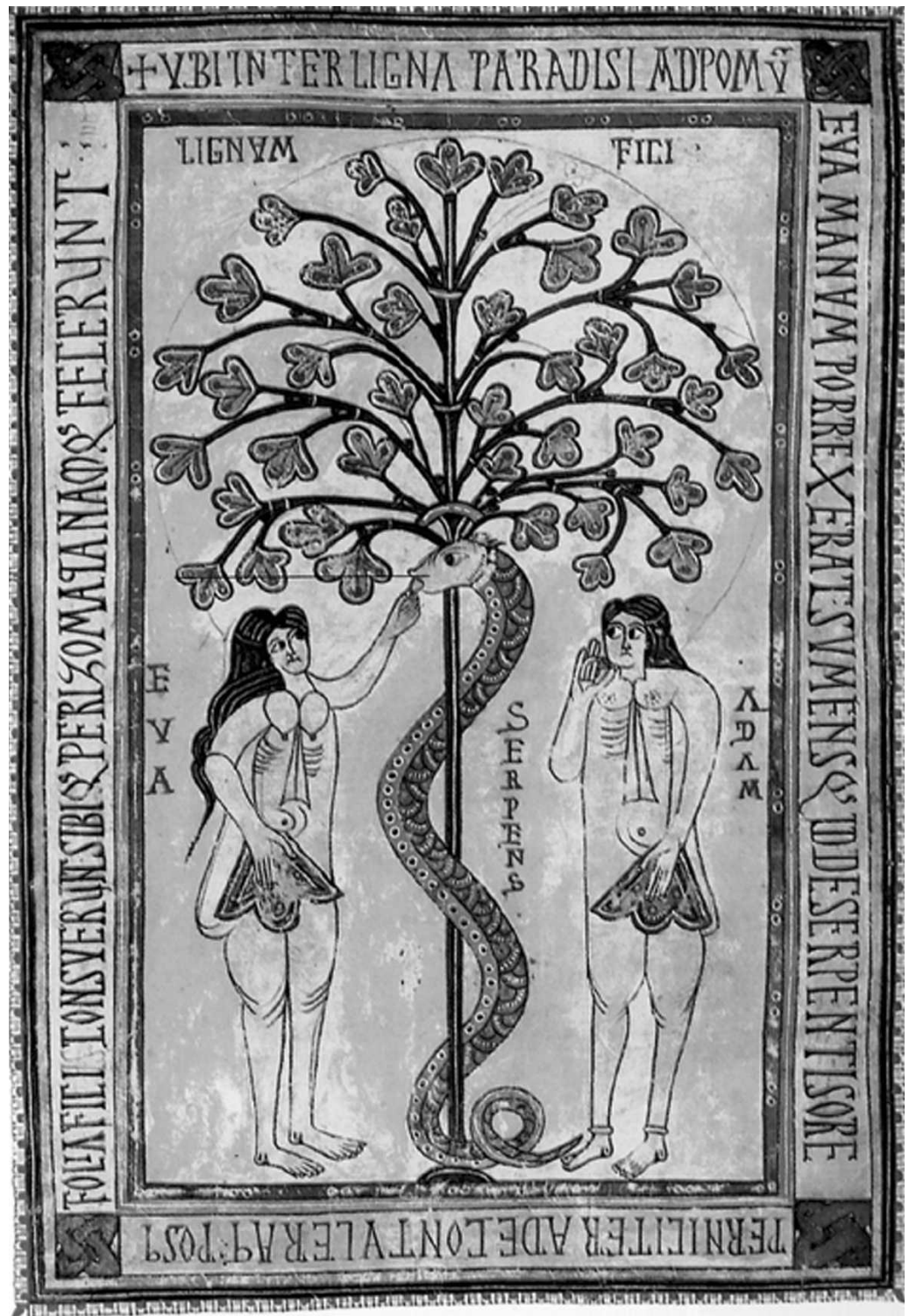

Fig. 5. Adam, Eve, and the Tree of Good and Evil, Codex Aemilianensis, 994, Escorial, Real, Biblioteca de San Lorenzo. Note that the tree is depicted as a fig tree. 

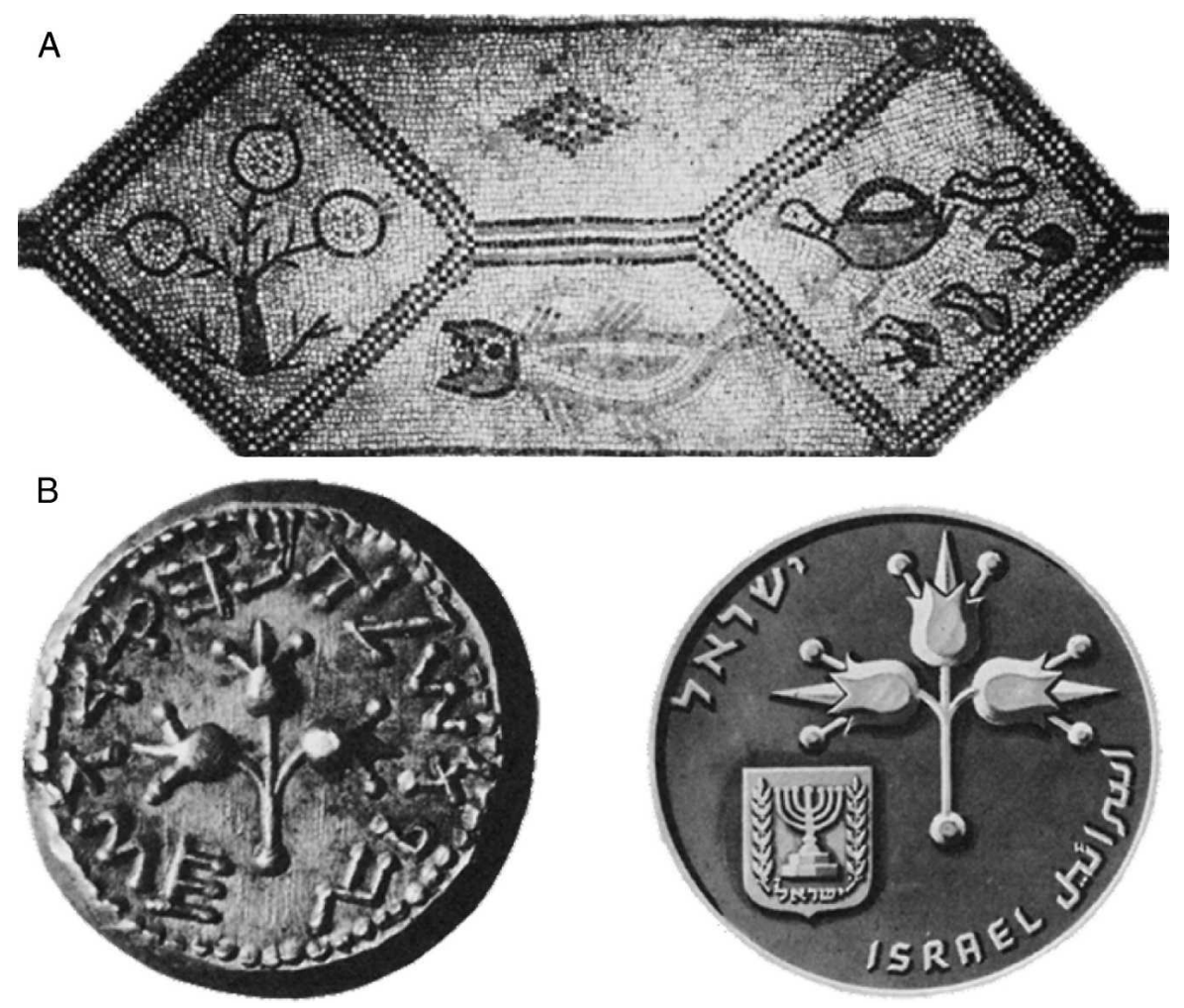

B

Fig. 6. (A) Mosaic from the synagogue at Beth Alfa showing a pomegranate tree, birds, and fish. (B) Jewish coins, ancient and modern, with pomegranate motif. Source: Goor and Nurock, 1968.

A certain man had a fig tree planted in his vineyard; and he came and sought fruit thereon, and found none. Then said he unto the dresser [cultivator] of his vineyard, Behold, these three years I come seeking fruit on this fig tree, and find none; cut it down; why cumbereth it the ground? And he answering said unto him, Lord, let it alone this year also, till I shall dig about, and dung it: And if it bear fruit, well: and if not, then after that thou shalt cut it down. Luke 13:6-9

I swear by the fig and the olive. Qur'an, The Fig-tree:95.001

\section{POMEGRANATE (Punica granata)}

Native to the southern Caspian belt (Iran) and Northeast Turkey, the pomegranate is a Bronze Age fruit that has been cultivated for 5000 years. The fruit was once known as the apple of Carthage, hence the Latin name Punica. The pomegranate was introduced into Egypt from Syria $\approx 1600 \mathrm{BCE}$ and reached Egypt though the inflow of Semitic people (Hyksos). The pomegranate is widely used in Jewish iconography (Fig. 6A) and coins (Fig. $6 \mathrm{~B})$. Based on these images, the pomegranate seems little changed from antiquity. Skin color varies from bright red to leathery brown. The pomegranate was long admired for its medicinal properties, and current interest is increasing for this reason. Although the pomegranate is not mentioned in the Christian bible, this fruit is widely used in Christian iconography of the Renaissance.

\section{Biblical references}

And he made the pillars, and two rows round about upon the one network, to cover the chapiters [capitals] that were upon the top, with pomegranates ... and the chapiters upon the two pillars had pomegranates also above, over against the belly which was by the network: the two pillars had pomegranates also above, over against the belly which was by the network: and the pomegranates were two hundred in rows round about the other chapiter. I Kings 7:18, 20

I would cause thee to drink of spiced wine of the juice of my pomegranate. Song of Songs 8:2

And He it is Who sends down water from the cloud, then We bring forth with it buds of all (plants), then We bring forth from it green (foliage) from which We produce grain piled up (in the ear); and of the palm-tree, of the sheaths of it, come forth clusters (of dates) within reach, and gardens of grapes and olives and pomegranates, alike and unlike; behold the fruit of it when it yields the fruit and the ripening of it; most surely there are signs in this for a people who believe. Qur'an, The Cattle:6.099

\section{ALMOND (Prunus amydalus)}

Almonds grow wild throughout Southwest and Central Asia, from Turkey and Syria into the Caucasus and into the deserts of Tian-shan and the Hindu Kush mountains. Based on biblical literature, almonds were introductions into the Holy Land as early as 2000 BCE. There are two principal types: sweet and bitter (amygdalin containing). Domestication involves selection for nonbitterness as a result of a single dominant gene (Kester and Gradziel, 1996) and increased kernel size. The famous sprouting rod of Aaron, mentioned in the Book of Numbers

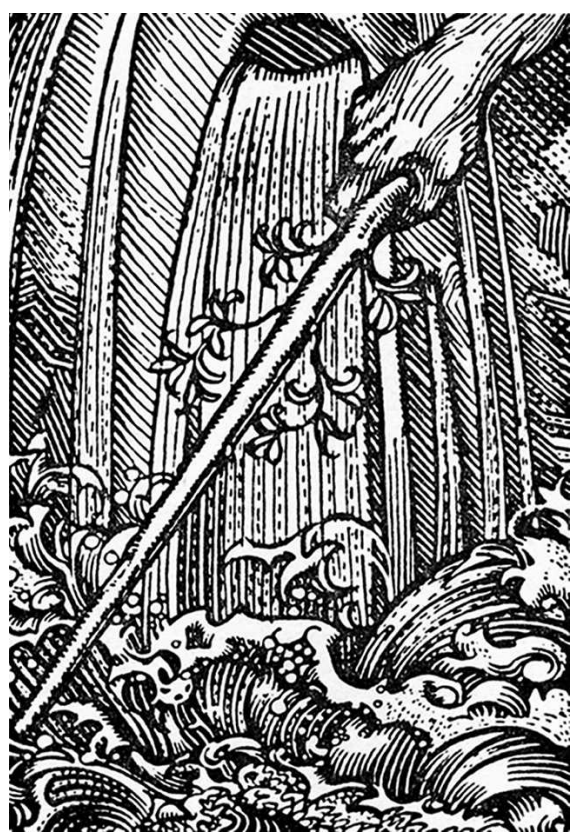

Fig. 7. Moses striking the rock with a sprouting almond rod. Source: Moldenke and Moldenke, 1952.

signifying that he and his descendants could be priests, was an almond (Fig. 7).

\section{Biblical references}

Three bowls made after the fashion of almonds in one branch, a knop (calyx) and a flower; and three bowls made like unto almonds in another branch, a knop and a flower: so throughout the six branches going out of the candlestick. And in the candlestick were four bowls made like almonds, his knops and his flowers. Exodus 37:19-20

And it came to pass, that on the morrow Moses went into the tabernacke to witness; and, behold, the rod of Aaron for the house of Levi was budded, and brought forth buds, and bloomed blossom, and yielded almonds. Numbers 17:1-8 (Fig. 7)

\section{Literature Cited}

Galil, J. 1968. An ancient technique for ripening sycamore fruit in East-Mediterranean countries. Econ. Bot. 22:178-190.

Janick, J. 2005. The origins of fruits, fruit growing, and fruit breeding. Plant Breed. Rev. 25:255320.

Goor, A. and M. Nurock. 1968. The fruits of the Holy Land. Israel University Press., Jerusalem.

Kester, D.E. and T.M. Gradziel. 1996. Almonds, p. 49. In: J. Janick and J.N. Moore (eds.). Fruit breeding, Vol. III, Nuts. Wiley, New York.

Moldenke, H.H. and A.L. Modenke. 1952. Plants of the bible. Chronica Botanica, Co., Waltham, MA.

Shakir, M.H. 1983. Holy Qur'an [English translation]. Tahrike Tarsile Qur'an, Inc. Elmhurst, NY.

Singer, C., J.H. Holmyard, and A.R. Fall. 1954. A history of technology. Vol. 1, From early times to ancient empires. Oxford University Press, London.

Walsh, C.E. 2000. The fruit of the vine: Viticulture in ancient Israel. Eisenbrauns, Winona Lake, IN. 